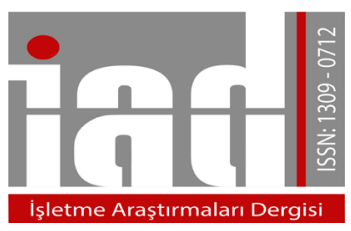

\author{
İşletme Araştırmaları Dergisi \\ Journal of Business Research-Turk \\ 10/4 (2018) 358-383
}

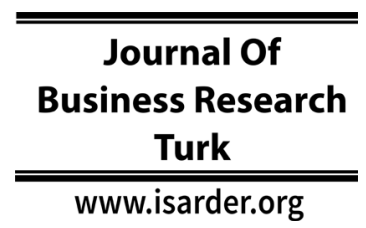

Araștırma Makalesi

\title{
Ankara Üniversitesi TÖMER'in Tüketici Temelli Marka Denkliği Bileşenlerinin Analizi \\ The Analysis of Customer Based Brand Equity Components of Ankara University TÖMER
}

\author{
Dilber ULAŞ \\ Ankara Üniversitesi \\ Arcan TUZCU \\ Ankara Üniversitesi \\ Siyasal Bilgiler Fakültesi, İşletme Bölümü \\ Ankara, Türkiye \\ orcid.org/0000-0002-7892-2406 \\ ulas@politics.ankara.edu.tr \\ Siyasal Bilgiler Fakültesi, İşletme Bölümü \\ Ankara, Türkiye \\ orcid.org/0000-0001-6342-735X \\ tuzcu@,politics.ankara.edu.tr
}

\author{
Esra SATICI \\ Karayolları Genel Müdürlüğü \\ Ankara, Türkiye \\ orcid.org/0000-0002-6784-182X \\ esra.satici@gmail.com
}

\section{Özet}

TÖMER, 1984 yılında yabancılara Türkçe öğretmek amacıyla "Türkçe Öğretim Merkezi" adıyla kurulmuştur. Kurum, Avrupa Dil Pasaportu verme yetkisi alan ilk dil merkezidir. "TÖMER" markası, 2013 yılında tescil edilmiştir. Bu çalışmada TÖMER' in marka denkliği bileşenleri incelenmiştir. Marka denkliği, marka ismine bağlı olarak ürünün artan değeridir. Marka denkliği yüksek olan markalar daha fazla tercih edilmektedir. Marka denkliği bileşenleri, marka çağrışımı, marka farkındalığı, marka sadakati ve algılanan kaliteden oluşmaktadır. Araştırmada örneklem seçimine gidilmeden, kayıtlı 2983 öğrenciye anket uygulanmış ve 1801 öğrenciden $(\%$ 60,4) geri dönüş sağlanmıştır. Elde edilen sonuçlara göre; marka çağrışımı yüksek düzeyde bulunmuş, ancak TÖMER'e yönelik algılanan kalite ve marka sadakatinin orta düzeyde olduğu saptanmıştır. Ayrıca marka sadakati ile marka çağrışımı, farkındalığı ve algılanan kalite bileşenleri arasındaki ilişki çoklu regresyon analizi ile araştırılmış; algilanan kalitenin marka sadakati üzerinde diğer değişkenlere göre daha etkili olduğu görülmüştür. Marka denkliği bileşenlerinin kullanıldığı bir faktör analizi yardımıyla TÖMER'in marka denkliği hesaplanmış ve bu denkliğin orta düzeyde olduğu belirlenmiştir.

Anahtar Kelimeler: Tüketici Temelli Marka Denkliği, Marka Sadakati, Algılanan Kalite, Marka Çağrışımı, Marka Farkındalığı, TÖMER.

Gönderme Tarihi 26 Eylül 2018; Revizyon Tarihi 13 Kasım 2018; Kabul Tarihi 20 Kasim 2018 


\begin{abstract}
TÖMER was founded in 1984 in order to teach Turkish to the foreigners under the name of "Turkish Education Center". This institution is the first language center that has the right to give European Language Passport. The brand "TÖMER" is registered in 2013. In this paper, the brand equity components of TÖMER have been investigated. Brand equity is the increasing value of the product based on the brand name. The brands with high brand equity are preferred more. The components of brand equity are brand association, brand awareness, brand loyalty and perceived quality. In this study, a questionnaire is applied to the 2983 registered students without choosing a sample, and a feedback is obtained from 1801 students (60,4\%). The findings show that the brand association is found to be high, but the perceived quality of TÖMER and its brand loyalty are in medium level. In addition, the relation between brand loyalty and brand association, brand awareness and perceived quality components is investigated through a multiple regression analysis. It is observed that the perceived quality has a higher impact on brand loyalty relative to the other variables. The brand equity of TÖMER is computed through a factor analysis that uses brand equity components and it is found as medium level.
\end{abstract}

Keywords: Customer Based Brand Equity, Brand Loyalty, Perceived Quality, Brand Association, Brand Awareness, TÖMER

Received 26 September 2018; Received in revised from 13 November 2018; Accepted 20 November 2018

\title{
Giriş
}

Aaker (1991) ve Keller (1993) tarafindan kavramsallaştırılan marka denkliği, 1990'larda doğan bir kavramdır. Aaker'a (1991) göre marka denkliği "bir markanın adının ya da sembolünün, bir ürün ya da hizmet tarafından bir firmaya atfedilen değerini arttıran veya azaltan unsurlarıdır." Kısaca "tüketicilerin bir marka ile ilişkilendirdiği değer" olarak ifade edilmektedir (Aaker, 1991). Bir başka ifadeyle, marka denkliği, tüketicilerin mal ve hizmetlere yüklediği ek değerdir. Bu değer, tüketicilerin markaya yönelik olumlu ve güçlü duygu, düşünce ve davranışlarıyla ilgili olduğu kadar fiyat, pazar payı ve karlılıkla da ilgilidir (Kircova, 2018). Marka denkliği; literatürde finansal temelli, çalışan temelli ve tüketici temelli bir bakış açısıyla incelenmiştir. Finansal perspektif bilançoda yer alan bir varlık olarak markanın parasal değerinin belirlenmesine, çalışan temelli perspektif çalışma ortamına ve marka bilgisi konusuna odaklanmaktadır. Tüketici temelli marka denkliği ise pazarlama perspektifi açısından tüketicinin karar verme süreciyle ilgilenmektedir ve bir markanın tüketici tarafından nasıl değerlendirildiğini daha etkili bir şekilde ortaya koymaktadır (Farjam ve Hongyi, 2015, s. 15). Marka denkliğini ilk belirleyen kesim tüketicilerdir. Bu çalışmanın amacı da, eğitim alanında önemli bir marka olan Ankara Üniversitesi TÖMER'in tüketici temelli marka denkliği bileşenlerini öğrencilerinin gözünden incelemektir.

Vazquez, Del Rio ve Iglesias (2002, s. 8) tüketici temelli marka denkliğini, "tüketicinin markayı kullanma ve tüketimi sonucunda elde ettiği sembolik ve fonksiyonel faydaların toplamı" şeklinde tanımlamıştır. Marka denkliğini oluşturmak için marka farkındalığı sağlamak ve marka sadakati oluşturmak önemlidir. Güçlü marka geliştirmek, tüketici sadakatini arttırmakta ve tüketicileri sürekli tüketici haline 
getirmektedir. İşletmelerin öncelikli hedefi güçlü bir marka oluşturmaktır. Tüketici temelli marka denkliği, tüketici markayı bildiğinde, marka farkındalığı yüksek olduğunda ve hafizasında güçlü marka çağrışımları bulunduğunda ortaya çıkmaktadır. Keller (1993) marka denkliğinin oluşmasında marka bilgisinin önemi üzerinde durmuştur. Pazarlamaya yapılan yatırım marka bilgisini (marka farkındalığı, çağrışımlar, davranışlar, sadakat vb.) etkilemektedir (Keller, 2002). Keller (1993, s. 2) tüketici temelli marka değerini "tüketicinin sahip olduğu marka bilgisine bağlı olarak işletmenin marka pazarlama faaliyetlerine tüketicilerin gösterdikleri olumlu veya olumsuz tepkiler" şeklinde tanımlamıştır. Müşteriler olumlu deneyime dayanan ürün ve hizmetler hakkında olumlu düşünmektedir. Dolayısıyla işletmeler müşterilerinde olumlu düşünceler, hisler, algılar yaratmalıdır. İşletmelerin uyguladıkları pazarlama çabaları ile tüketici temelli marka denkliği oluşturulmaktadır.

TÖMER, Ankara Üniversitesi'nin tescilli markasıdır., Ankara ve İstanbul'da iki, İzmir, Bursa, Antalya ve Alanya'da birer olmak üzere Türkiye çapında toplam sekiz noktada dil eğitimi vermektedir. Ayrıca ülke dışında da temsilcilikleri bulunmaktadır. Dil eğitiminde öğrencilerin dili rahatlıkla konuşabilen, yazabilen bireyler haline gelebilmesi çok önemlidir. Günümüzde "eğitimde marka olma" devri yaşanmaya başlamıştır. Başarılı markalar geliştiren kurumlar rekabet avantajları elde etmektedir. $\mathrm{Bu}$ nedenle, bu çalışma TÖMER'in tüketici temelli marka denkliği bileşenlerini araştırarak katkı sunmaktadır. Bu amaçla, öğrencilerin TÖMER'i tercih etmeleri için marka adının yeterli olup olmadığı, TÖMER'e yönelik marka farkındalığının, marka sadakatinin olup olmadığı, TÖMER'in marka çağrışımı ve algılanan kalite gibi marka denkliği bileşenleri araştırılmıştır.

\section{Kavramsal Çerçeve}

\subsection{TÖMER ve Tüketici Temelli Marka Denkliği}

Eğitim kurumlarının var olabilmeleri için tercih edilmeye, tercih edilmeleri için güçlü ve değerli bir markaya, bunun için de çok iyi hazırlanmış bir dil eğitim sistemine ihtiyaçları bulunmaktadır. Dil eğitimi veren kurumlar iyi bir meslek sahibi olmak, toplum ve iş hayatında daha iyi bir konuma gelmek, iyi ve ekonomik kazancı yüksek bir kariyer imkânı elde etmek için tercih edilmektedir. Eğitim hizmeti veren kurumların sadece güçlü bir eğitim kadrosuna ya da modern bir binaya sahip olmaları marka olmalarında yeterli değildir. Değişen dünyaya hızı bir şekilde ayak uydurmaları da gerekmektedir. TÖMER, 1980'lerde Türkçeyi yabancı dil olarak öğreten ilk ve tek kurum olarak hizmet vermeye başlamıştır. 1989 yılından itibaren İngilizce, Fransızca ve Almanca öğretimine başlanılan TÖMER'de günümüzde Türkçe, İ̉ngilizce, Almanca, Fransızca, İspanyolca, Portekizce, İtalyanca, Rusça, Bulgarca, Çince, Arapça, Korece, Farsça dilleri ve Osmanlı Türkçesi öğretilmektedir. Dil alanında yapılan bu çalışmalar TÖMER'e “bilimsel tabanlı dil merkezi” kimliğini kazandırmış ve TÖMER'in yabancı dil öğretiminde uygulanmak üzere yeni yöntem ve teknikler geliştirmesine olanak vermiştir. TÖMER'de yabancılar için Türkçe, Türkler için de yabancı dil eğitiminin yanı sıra, ilköğretim öğrencilerine yönelik genel amaçlı yabancı dil kursları da verilmektedir. TÖMER'de dil öğretimi, dört temel dil becerisinin eşit ağırlıklı olarak (okuma, dinleme, konuşma, yazma) geliştirilmesine dayalıdır. Öğretim etkinlikleri her sınıfta bulunan, televizyon, yansıtıcı, DVD oynatıcı gibi görsel-işitsel araçlarla desteklenmektedir. Tecrübeli ve uzman bir eğitim kadrosu, Ankara Üniversitesi'ne bağlı bir dil okulu olması ve bunun güvenilirliği, uluslararası geçerliliğe sahip diplomaları, 
kendine özgü eğitim metotları, tüm şubelerinde aynı metotlarının kullanımı TÖMER'in en güçlü yönleridir.

Amerikan Pazarlama Birliği'ne göre marka, "Bir ürün ya da bir grup satıcının ürünlerini ya da hizmetlerini belirlemeye, tanımlamaya ve rakiplerin ürünlerinden ya da hizmetlerinden farklılaştırmaya, ayırt etmeye yarayan isim, terim, işaret sembol, tasarım, şekil ya da tüm bunların bileşimidir" (www.ama.org).

Hizmet markası oluşturulurken güvenilir tüketici ilişkileri kurmak ve kaliteli hizmet deneyimi sunmak esastır (Alexandris ve Diğ., 2008). Tüketici temelli marka denkliği, kısaca markanın pazarlanmasına tüketicinin verdiği tepki ve marka bilgisi etkisi olarak tanımlanmaktadır. Kavram, markanın işletme ve tüketici için sağladığı yararların bütününü kapsar. Bir işletmenin ya da kurumun rakipleri arasında farklı konumda bulunmasını, markanın kalitesinin yüksek olarak algılanmasını ve marka sadakatini sağlayarak diğer markalara göre daha rekabetçi olmasını sağlayan önemli bir pazarlama stratejisidir. TÖMER, 30 yılı aşkın birikimiyle başta Türkçe öğretimi olmak üzere hizmet sektöründe gerçek anlamda marka olmuş bir kurumdur. Öyle ki TÖMER adı, 2013 yılında tescil edilmesine rağmen halihazırda dil eğitimi veren çok sayıda kamu ve özel kurum tarafından kullanılmaktadır.

\subsection{Marka Denkliği Bileşenleri}

Tüketici temelli marka denkliği bileşenleri Aaker'a göre marka farkındalığı, algılanan kalite, marka imajı ve marka sadakatinden oluşmaktadır (Seongseop, Choeb ve Petrickc, 2018, s. 321). Hizmet sektöründe çalışan işletmelerin güçlü marka yaratabilmeleri için farklılaştırılmış hizmet deneyimi sunmaları, tüketicilerin gözünde önemli olmaları, tüketicilerin markayla duygusal bağ ve iletişim kurmalarını sağlamaları, müşteri memnuniyetini yakalamaları, çalışanlarına önem vermeleri, hizmet odaklı çalışanları seçmeleri ve olumlu müşteri deneyimleri yaratmaları gerekmektedir. Marka denkliğini doğru olarak anlayarak uygulayabilen ve farkındalık oluşturabilen hizmet işletmeleri, müşterilerine kaliteli hizmet vererek, müşteri memnuniyeti sağlayarak ve sadık müşteriler oluşturarak performanslarını arttırabileceklerdir. Boyle (2007) tüketici temelli marka denkliği oluşturmada benzeri olmayacak özelliklerde algılanan bir ürün geliştirmenin, pazarlama ve iletişim kanalları yoluyla marka farkındalığı sağlamanın, tüketim öncesinde pazarlama ve iletişim sayesinde marka çağrışımları oluşturmanın ve tüketim sonrasında da elde edilen benzersiz faydaların marka sadakatine yol açtı̆̆ı üzerinde durmuştur. Marka denkliği yaratılması sürecine tüketicinin katılımının sağlanması önemlidir (Kuvykaite ve Piligrimiene, 2014, s. 481). Marka farkındalığı, algılanan kalite ve marka çağrışımını; olumlu marka çağrışımı ise marka sadakatini etkilemektedir. Tüketici, markayı yüksek kalitede algıladığında, markaya düşkünlüğü ve sevgisi artmakta, sonuçta sadakatin oluşumu da artmaktadır.

\subsubsection{Marka Farkındalığı (Bilinirliği)}

Bir işletmenin mal veya hizmetlerinin diğer işletmelerin mal veya hizmetlerinden ayırt edilmesi, marka sahibi olan işletmeye pazarlama, tüketicilere ise seçim yapma imkânı verir. Marka farkındalığı, potansiyel bir alıcının belirli bir ürün kategorisine ait markayı tanıması veya hatırlaması yeteneği anlamına gelir. Marka tanıma, tüketicilerin belirli markalara aşina olmasıdır. Tüketicinin bir logoyu gördüğünde tanıması gibi. Marka hatırlama, belli bir durumda ipucu verildiğinde belirli markaları hatırlayabilme becerisini ifade etmektedir. "Aklınıza gelen ilk üç fast food restoranını listeler misiniz?" sorusu sorulduğunda ilk akla gelen marka olmak buna örnek verilebilir (Baalbaki ve 
Guzmán, 2016, s. 34). Marka denkliği oluşturmanın ilk adımı, marka farkındalığını inşa etmektir (Aaker, 1991, s. 61).

Keller'in modeline dayanarak Kuhn, Alpert ve Pope (2008), güçlü bir marka oluşturmanın ilk adımının, doğru marka kimliğinden (marka adı, logo, slogan, marka kahramanı, marka müziği vb.) geçtiğini belirtmiştir. Hangi ihtiyacı tatmin ettiğinin belirlenmesi, kategori tanımlaması yapılması önemlidir (Farjam ve Hongyi, 2015, s. 19). Marka; tüketicilerin bilgilenme ve ürüne duydukları güven açısından yönlendirici bir işleve sahip olup, ürünün adını, görsel kimliğini veya ürünü tanımanın çok ötesine geçmiştir. Markanın oluşturulmasından sonraki adım, bu markanın potansiyel tüketicilerce bilinmesini sağlamaktır. Tüketicilerin haberdar olmadığı bir markanın ne kadar kaliteli ya da farklı olduğunun bir anlamı olmayacaktır. Marka farkındalığı, yalnızca marka ismini bilmek ya da markayı daha önce görmüş olmak anlamına gelmemektedir. Markanın ayrıca tüketicinin zihninde marka ismi, marka sembolü gibi çağrışımları da birleştirmesidir (Hoeffler ve Keller, 2003). Marka farkındalığı; markayı hatırlamak üzere tüketiciye verilen ürün kategorisi arasından o markanın seçilebilme kabiliyetidir. Marka denkliğinin oluşması, marka farkındalığının yaratılması ile başlamaktadır (Chieng ve Lee, 2011, s. 36). Marka farkındalığı, markanın tüketiciler tarafından tanınması ve tüketici zihninde belirli bir ürün grubu ya da tüketici ihtiyacı ile ilişkilendirilmesinin sağlanmasıdır. Ürüne ait olan ihtiyaç ortaya çıktığında, tüketicilerin akıllarına ilk olarak belirli bir markanın gelmesi sağlanırsa marka farkındalığı sağlanmış demektir. Markaya ait olan tüm öğelerin birlikte ve aynı anda tüketici zihninde yer alması gerekmektedir. Marka farkındalığı marka denkliği konusunda önemli ama göz ardı edilen bir unsurdur. Farkındalık, algıları ve tutumları değiştirebilmekte ve bazı durumlarda marka seçiminde ve hatta marka sadakatinde kilit rol oynayabilmektedir. Bir başka deyişle, farkındalık bir markanın tüketiciler için önemini ortaya koymaktadır. Marka farkındalığının; tanıma, hatırlama, akılda en fazla yeri tutabilme, marka hâkimiyeti, marka bilgisi ve marka fikri şeklinde çeşitli düzeyleri bulunmaktadır (Aaker, 1996; Pitta ve Katsanis, 1995).

Marka farkındalığının oluşturulabilmesi için çeşitli iletişim araçları kullanılabilir. Tüketiciler, satın alma kararlarını geleneksel reklam yöntemleri yanında tanıdıklarından gelen tavsiyeler (fisıltı reklamı) ve doğrudan deneyim bilgileri üzerine de şekillendirmektedirler. İnteraktif pazarlama (internet, TV, bloglar, tweetler, online reklamlar) marka farkındalığını arttırabilir. Potansiyel olarak ulaşılması zor gruplar hedeflenerek interaktif pazarlama ile marka farkındalığı oluşturulabilir (Keller, 2010, s. $62)$.

\subsubsection{Marka Çağrışımı}

Marka denkliği bileşenlerinden ikincisi olan marka çağrışımı; tüketicinin zihninde marka ile ilgili tüm düşünceleri, duyguları, deneyimleri ifade etmektedir. Marka farkındalığı ile arasında güçlü bir bağ vardır. Aaker (1991) ve Keller (1993)'a göre de marka çağrışımı, tüketicinin zihninde marka ile ilgili tüm düşüncelerdir (Foroudi ve Diğ., 2018, s. 463). Çağrışımlar ürün ya da hizmet sunumu, inovasyon, saygınlık, çalışan personel, fiziksel koşullar, kullanıcı, kullanım ve fiyat ile ilgili olabilir. Markaya karşı olumlu tutumlar ve hisler oluşturulurken, markayı kullanmanın sağlayacağ faydaları önermede marka çağrışımları kullanılmaktadır. Marka çağrışımı markayla ilişkilendirilen ürün özelliklerini, somut ve somut olmayan bazı çağrışımları kullanmak ve tüketicilerin zihninde marka anlamını yerleştirmektir. Tüketici zihninde birbirleri ile 
ilişkilendirilen bu kavramlar sayesinde, tüketicilerin markayı anlamaları ve yorumlamaları da kolaylaşmış olmaktadır. Marka çağrışımı; müşteri hizmetleri, üründen duyulan memnuniyet, güvenilirlik, dayanıklılık, fiyat, ürün işlevselliği vb. unsurları kapsamaktadır (Budac ve Baltador, 2013, s. 445).

Marka denkliğinin yüksek olması, sadece markanın faydaları ile değil, yaratacağı çağrışım desteği ile de gerçekleşmektedir. İşletmelerin ürünlerini farklılaştırmada kullanabilecekleri çağrışımlar; tüketici yararına yönelik, ürün ve hizmet özelliklerine yönelik, ürün kullanımı ya da uygulamalarına yönelik, tüketiciye yönelik, ünlü kullanımına yönelik, hayat tarzı-kişiliğe yönelik, ülke orijinine ve rakiplere yönelik olabilir.

\subsubsection{Algılanan Kalite}

Marka farkındalığı ve marka imajı oluşturulduktan sonra, hedef kitlede markanın kaliteli ve tüketiciler açısından değerli olan özelliklere sahip olduğuna dair algının oluşturulması önemlidir. Bunun için olumlu tüketici tepkisi ile kalite algısı oluşturulmaya çalışılır. Tüm bu pazarlama faaliyetlerinin nihai amacı, tüketicinin belirli markalara rakip markalardan farklı yaklaşmalarını olanaklı kılmaktır.

Zeithaml (1988), algılanan kaliteyi, marka denkliğinin bir bileşeni olarak tanımlar. Aaker (1991) ve Keller (1993) ise algılanan kaliteyi tüketicinin genel kalite algısı olarak tanımlamaktadır. Algılanan kalitede tüketiciler, beklentilerini gerçekleşen hizmet anlayışı ile karşılaştırır (Liu ve Diğ., 2017, s. 194). Bir başka deyişle, , tüketicilerin beklentilerinin, onlar açısından karşılanma düzeyidir. $\mathrm{Bu}$ düzey, tüketiciler arasında da farklı değerlendirilmektedir. Algılanan kalite, tüketicilerin beklentileri ile uyumluluk gösteriyor ise tüketici tatmininin sağlanmasında olumlu yönde etkide bulunmakta; tüketici beklentileri ile uyumsuzluk söz konusu ise tüketici tatmini üzerinde olumsuz yönde bir etki yaratmaktadır.

Algılanan kalite, aslında marka hakkında hissedilen soyut bir kavramdır. Daha çok güvenilirlik ve performansa, hizmetin güvenilirliğine, garantilere, fiziksel koşullara ilişkin olabilir. Tüketicilerin ürün hakkındaki algıları, yargıları, düşünceleri ve inançlarıdır. Fiyata bağlıdır. Tüketiciler, benzer ürünler için yüksek fiyatlı gördükleri ürünleri yüksek kaliteli algılamaktadır. Bu nedenle, markaya karşı olumlu tutumlar için bir itici güçtür. Tüketiciler, yüksek kalitede algıladıkları ürünlere güvenmektedir (Foroudi ve Diğ., 2018, s. 463).

Algılanan kalite, ürünün şekil ve görünüm gibi fiziksel özellikleriyle ya da marka adı, mağaza, ambalaj, üretim bilgileri, fiyat, tutundurma, paketleme gibi fiziksel olmayan özellikleriyle de değerlendirilebilir (Steenpkamp, 1997; Zeithaml, 1988). Yüksek algılanan kalite tüketicinin markayı satın almaya ikna olmasını, işletmenin rakiplerinden farklılaşmasını ve yüksek fiyat talep etmesini sağlar (Aaker, 1991).

\subsubsection{Marka Sadakati (Bağlılığı)}

Marka sadakatinin oluşturulmasının işletme ve marka başarısı açısından hayati bir önemi bulunmaktadır. Marka sadakati, tüketicinin her defasında aynı markayı satın almayı tercih etme eğilimi olarak tanımlanabilir (Krystallis ve Chrysochou, 2014, s. 141). Bu kavram, davranışsal ve bilişsel olarak ele alınabilir. Davranışsal marka sadakati, tüketicinin sadece içinde bulunulan zamanda değil, gelecek dönemlerde de belirli bir markayı satın almasıdır. Tekrarlanan alım sayısı, markayı birincil olarak yeniden satın alma taahhüdü ile ilgilidir. Davranışsal sadakat, 
tüketicilerin aynı hizmet sağlayıcısının ürettiği ürünleri kullanmayı düşünüp düşünmedikleri veya söz konusu markayı diğer insanlara tavsiye edip etmeyecekleri ile ilgilidir. Marka sadakatini ölçmek için, markayı diğer insanlara tavsiye etme, diğer markaları kullanmama, markayı beğenme dikkate alınmaktadır.

Bilişsel sadakat ise bir markanın ilk olarak akla gelmesidir. Satın alma kararı verildiğinde tüketicinin ilk seçimidir. En üst düzeyde farkındalıkla yakından ilgilidir ve tüketicilerin ilk önce hatırladıkları belirli bir kategorideki markadır. Bir marka, katılımcıların ilk tercihleri haline gelebilmekte (bilişsel sadakat) ve bu nedenle tekrar tekrar satın alınmaktadır (davranışsal sadakat) (Fayrene Chieng ve Lee, 2011, s. 39). Marka denkliği, o markanın oluşturduğu sadık tüketiciler tarafından gerçekleştirilmektedir (Keller, 1993). Markaya sadık olan tüketicinin bugün ve gelecekte aynı markayı satın alma olasılığı çok yüksektir (Lin, Wu ve Wang, 2000, s. 279). Marka sadakati, hep aynı markanın tercih edilmesi, markanın değiştirilmemesi ve alışveriş yapılan mağazada bulunamazsa aynı markanın başka bir mağazadan satın alınmasıdır. Hep aynı markanın alınması, filmleri hep aynı sinemada izlemek, çoğunlukla hizmet alınan aynı yere gitmek marka sadakatine örnek olarak verilebilir. McConnell (1968, s. 14), marka sadakatini başka markaya geçmeden üst üste deneme olarak tanımlamıştır. Keller (1993), sadakatin bir ürünü yeniden alma sıklığıyla veya söz konusu markayı tekrar alma konusunda ilk tercih olarak kabul edebilme imkânına göre ölçüldüğünü belirtmiştir.

Marka sadakatini ölçmek için; tekrar satın alma oranları, satın alma sıklığı, satın alınan marka sayısı, marka için daha yüksek fiyat ödemeye hazır olma ve markayı diğerlerine tavsiyelerde bulunma şeklinde farklı yöntemler kullanılabilir (Miller ve Grazer, 2003, s. 83).

\section{Yöntem}

Daha önce de belirtildiği gibi, marka denkliği bileşenleri; marka adı çağrışımı, marka farkındalığı, marka sadakati ve algılanan kaliteden oluşmaktadır. Bu çalışmanın amacı da, TÖMER'in marka denkliği bileşenlerini değerlendirmek ve bu bileşenler arasındaki ilişkileri belirlemektir.. Bu nedenle, TÖMER'in öğrencileri tarafından marka denkliği bileşenleri bağlamında nasıl algılandığı, öğrencilerin TÖMER'i tercih etmeleri için marka adının yeterli olup olmadığı, TÖMER'e yönelik marka farkındalığının ve marka sadakatinin olup olmadığ 1 ve TÖMER markasına yönelik algılanan kalitenin düzeyi belirlenmeye çalışılmıştır. Ayrıca, marka sadakati ile marka çağrışımı, farkındalığı ve algılanan kalite bileşenleri arasındaki ilişki araştırılmıştır. Son olarak marka denkliği bileşenleri kullanılarak TÖMER'in marka denkliği hesaplanmıştır.

\subsection{Araştırma Modeli}

Marka denkliğinin dört bileşeni olan marka farkındalığı, algılanan kalite, marka çağrışımı ve marka sadakati arasında etkileşime dayalı bir ilişki ağı mevcuttur. Belirli bir marka adını bilmeyen, duymayan veya farkında olmayan biri için markanın kalitesi veya yaygın bir çağrışım duygusu neredeyse hiçbir şey ifade etmez, bunlar olmadan da marka sadakatine ilişkin herhangi bir duygudan bahsedilemez. Bu bağlamda ilk olarak bu değişkenler arasındaki ilişki incelenmiş, ardından da ilk üç değişkenin (marka farkındalığı, marka çağrışımı ve algılanan kalite) ne ölçüde marka sadakatinin belirleyicileri olduğu analiz edilmiştir. Araştırma modeli, Şekil 1'deki gibi gösterilebilir. 


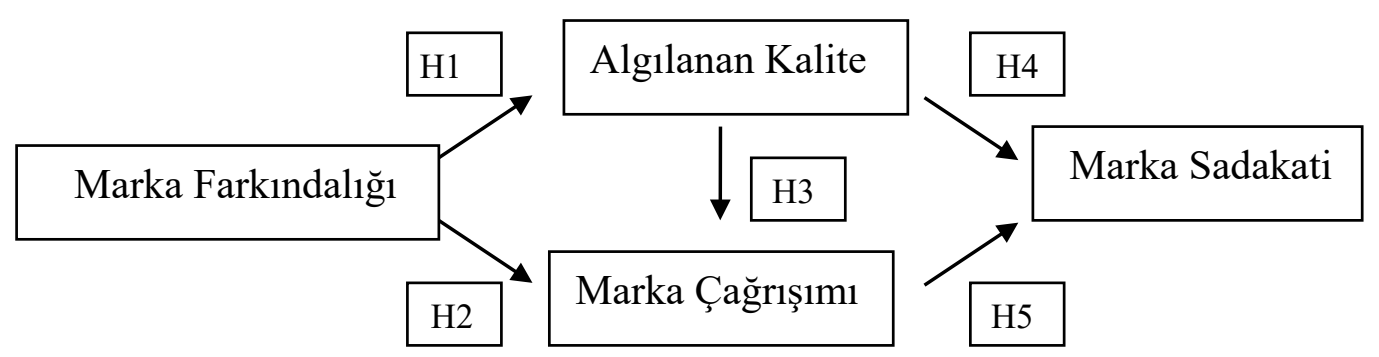

\section{Şekil 1: Marka Denkliği Bileșenleri Modeli}

Marka farkındalı̆̆ı, marka denkliğinin temelidir (Gartner ve Konecnik Ruzzier, 2011). Buna bağlı olarak artan marka farkındalı̆ğ daha iyi algılanan kaliteye (Yoo, Donthu ve Lee 2000) ve daha iyi marka çağrışımına yol açmaktadır (Villarejo-Ramos ve Sanchez-Franco, 2005). Bu nedenlerle aşağıdaki hipotezler oluşturulmuştur.

$\mathrm{H}_{1}$ : Marka farkındalığ

$\mathrm{H}_{2}$ : Marka farkındalığı, marka çağrışımı ile ilişkilidir.

Park, Robertson ve Wu (2004) algılanan kalitenin, marka farkındalığını olumlu yönde etkilediğini belirtmektedir. Aydın ve Özer (2005), marka imajının tüketicilerin biriken deneyimlerinden ve algılanan hizmet ve ürün kalitesinden kaynaklandığını vurgulamaktadır. $\mathrm{Bu}$ nedenle, algılanan kalitenin doğrudan marka çağrışımını etkileyeceği sonucuna varılabilir. Ayrıca müşteriler belirli bir markanın yüksek kalitede olduğunu algılarsa, bu markayı sürekli olarak satın alma ve başkalarına tavsiye etme eğilimindedirler (Jones, Mothersbaugh ve Beatty, 2002; de Ruyter, Wetzelz ve Bloemer, 1998). Bu durum, iyi kalite algısının marka sadakatini artırmaya yardımc olacağı anlamına gelir. Dolayısıyla üçüncü ve dördüncü hipotezler aşağıdaki gibi oluş̧urulmuş̧ur.

$\mathrm{H}_{3}$ : Algılanan kalite, marka çağrışımı ile ilişkilidir.

$\mathrm{H}_{4}$ : Algılanan kalite, marka sadakati ile ilişkilidir.

Marka imajı/çağrışımları da marka sadakati üzerinde güçlü bir pozitif etkiye sahiptir (Park Robertson ve Wu, 2004). Başka bir deyişle, markanın iyi bir marka çağrışımı varsa, insanlar markaya daha sadıktırlar. Buradan hareketle şu hipotez oluşturulmuş̧ur.

$\mathrm{H}_{5}$ : Marka çağrışımı, marka sadakati ile ilişkilidir.

Son olarak, modelde yer alan ilk üç değişkenin (marka farkındalığı, marka çağrışımı ve algılanan kalite) marka sadakatinin belirleyicileri olduğu görülmektedir (Chow ve Diğ., 2017). Marka sadakati, bu üç değişken kullanılarak çoklu regresyon analizi ile modellenmiştir.

$\mathrm{H}_{6}$ : Marka sadakati, marka farkındalı̆̆ etkilenmektedir. 


\subsection{Araştırma Evreni ve Örneklem}

TÖMER öğrencilerine yönelik yapılan anket çalışmasının evrenini TÖMER'in şubelerinde tüm dillerde açılmış sınıflara kayıtlı "yetişkin" öğrenciler oluşturmaktadır. Araştırmaya katılanlar TÖMER'e kayıtlı Türk öğrenciler ve kurs ücretini kendi karşılayan yabancı uyruklu öğrencilerdir. Tüm burslu yabanc1 öğrenciler (Yurt Dışı Türkler ve Akraba Toplulukları ile Afgan ve Libya hükümet bursluları vb.) kapsam dış1 tutulmuştur. Anket altı dile çevrilmiştir. Soru formları TÖMER şubelerine hedef kitleye uygulanmak üzere gönderilmiş ve örneklem seçimine gidilmeden tam sayım ile anketlerin sınıflarda uygulanması sağlanmıştır. Toplam 2983 öğrenciden 1801 'inden $(\% 60,4)$ geri dönüş sağlanmıştır.

\subsection{Kullanılan Ölçme Araçları}

TÖMER markasının tüketici temelli marka değerini oluşturan boyutları değerlendirmek için Zeithaml (1988), Aaker (1991, 1996), Keller (1993), Pitta ve Katsanis (1995), Miller, ve Grazer (2003), Krystallis ve Chrysochou (2014) ve Baalbaki ve Guzmán (2016) tarafından geliştirilen ve çok boyutlu tüketici temelli marka değer ölçeğinde kullanılan yargı ifadeleri kullanılmıştır. 5'li Likert ölçeği kullanılarak cevaplayıcılardan her bir yargıya ne derece katıldıklarını belirtmeleri istenmiştir. Ölçeklerde "1-kesinlikle katılmıyorum, 5-kesinlikle katıliyorum"u temsil etmektedir. 15 kişiye ön test yapıldıktan sonra soru belgesine son şekli verilmiş ve anket uygulanmıştır. Soru formu, biri demografik kısım olmak üzere üç bölümden oluşmaktadır.

IBM SPSS 24 istatistik paket programına veri girişleri yapılarak, gerekli kontrollerden sonra belirlenen hipotezler yine aynı program yardımıyla sınanmıştır. Ankette yer alan 5'li Likert ölçeğinde yöneltilen 39 soruya ilişkin güvenilirlik analizleri yapılmıştır. Buna göre elde edilen Cronbach's Alpha değeri 0,903 bulunarak ölçeğin yüksek derecede güvenilir olduğu görülmüştür.

Marka denkliği bileşenlerinden, marka çağrışımı, marka sadakati ve algılanan kalite için yapılan güvenilirlik analizlerinde içsel tutarlılıklar değerlendirilerek sorulara verilen cevaplar, yüzlük puan sisteminde değerlendirilerek marka denkliği bileşen değerleri elde edilmiştir. Marka farkındalığını ölçmeye yönelik sorular 5'li Likert ölçeğine göre hazırlanmadığı için, farkındalık puanı ağırlıklı ortalama yoluyla elde edilmiştir.

\subsection{Hipotezlerin Test Edilmesi}

Belirlenen değişkenlere ilişkin kurulan hipotezlerin sınaması varsayım değerlendirmeleri yapıldıktan sonra gerçekleştirilmiş ve yorumlanmıştır. Buna göre, normal dağılım göstermeyen bileşenlerin istatistiksel olarak farklı olup olmadıklarını araştırmak için bağımsız örneklem testlerinde parametrik olmayan istatistiksel yöntemlerden (Kruskall Wallis ve Mann-Whitney U testi) faydalanılmıştır. Marka denkliği bileşenleri arasındaki ilişki, Spearman korelasyon analizi ile araştırılmıştır.

Marka denkliği bileşenlerinin incelenmesinde ve yapılan analizler sonunda, marka sadakatinin oluşmasında, incelenen diğer bileşenlerin katkısı olduğu görülmüştür. Marka sadakatinin; marka farkındalığı, algılanan kalite ve marka çağrışımı değişkenlerinin fonksiyonu şeklinde açıklanabilirliğini test etmek, sebep-sonuç ilişkisini araştırmak ve birlikte değişim oranlarını görmek amacıyla çoklu regresyon analizi uygulanmıştır. 
Son olarak; incelenen dört bileşen kullanılarak faktör analizi yardımıyla marka denkliği endeks değerleri elde edilmiştir. Elde edilen endeks değerleri yorumlanabilmesi açısından interpolasyonla 0-100 aralığına getirilmiştir.

\section{Bulgular}

\subsection{Demografik Veriler}

Ankete katılan öğrencilerin \% 60,8'i Türkçe, \% 39,2'si altı farklı dilde hazırlanan soru formunu doldurmuşlardır. Katılımcıların \% 63,7'si kadın, \% 36,3'ü erkektir. Katılımcıların \% 51'i üniversite veya lisansüstü eğitim seviyesine sahiptir. Lise mezunlarının oranı ise \% 31,3'dür. Katılımcıların yaş ortalaması ise 25'tir. Ankete katılan TÖMER kursiyerlerinin çoğu (Türk öğrencilerin \% 71,4'ü, yabancı öğrencilerin \% 36,5'i) öğrencidir. Türk kursiyerlerin \% 12'si özel sektör çalışanı iken \% 5,5'i ise çalışmamaktadır. Yabancı kursiyerlerin \% 33,5'i çalışmıyorken, \% 20,3'ü ise özel sektör çalışanıdır.

\subsection{TÖMER Marka Farkındalığının (Bilinirliğinin) Ölçülmesi}

Marka farkındalığı güçlü olan bir marka kolaylıkla fark edilebilir ve satın alınabilir. Aaker'e (1991) göre, insanlar tanıdıkları markayı satın almayı tercih ederken, bilinmeyen markanın satın alınma şansı daha az olmaktadır. Markası en çok tanınan markalar, eski markalardır. Eski olan markaya güven artı değer yaratırken, duygusal bağlar da sadakati arttırmaktadır. Marka farkındalığı; TÖMER logosunun hatırlanma derecesine, marka bilgisine (markanın neyi temsil ettiğini bilme) ve marka fikrine (marka hakkında Tablo 1'de belirtilen konularda fikir sahibi olma) dayalı olarak değerlendirilmiştir. Anket kapsamında öğrencilere TÖMER hakkında ne kadar bilgi sahibi oldukları sorulmuştur. Öğrencilerin \% 16'sı TÖMER hakkında herhangi bir bilgi sahibi olmadığını, \% 35,9'u az düzeyde, \% 39,6'sı orta düzeyde ve \% 8,6's1 üst düzeyde bilgi sahibi olduğunu belirtmiştir (Tablo 1).

\section{Tablo 1: TÖMER ile İlgili Konularda Öğrencilerin Bilgi Sahibi Olma Oranları}

\begin{tabular}{|l|c|c|}
\hline \multicolumn{1}{|c|}{ Farkındalığı Sınanan Konu } & $\begin{array}{c}\text { Evet } \\
(\mathbf{\% )}\end{array}$ & $\begin{array}{c}\text { Hayır } \\
(\mathbf{\%})\end{array}$ \\
\hline TÖMER'in Ankara Üniversitesine bağlı bir kurum olduğunu biliyorum & 95,6 & 4,4 \\
\hline TÖMER'in Türkiye genelinde şubeleri olduğunu biliyorum & 93,8 & 6,2 \\
\hline TÖMER'in Ankara Üniversitesi onaylı diploma verdiğini biliyorum & 92,3 & 6,1 \\
\hline $\begin{array}{l}\text { TÖMER adı kullanım hakkının sadece Ankara Üniversitesine ait } \\
\text { olduğunu biliyorum }\end{array}$ & 59,1 & 40,9 \\
\hline $\begin{array}{l}\text { TÖMER'in Avrupa Dil Portfolyosuna denk bir dil belgesi verdiğini } \\
\text { biliyorum }\end{array}$ & 51,6 & 48,4 \\
\hline $\begin{array}{l}\text { TÖMER tarafından yabancı uyruklu öğrencilere verilen Türkçe } \\
\text { yeterlilik diplomasının Türkiye'deki tüm üniversitelerde geçerli } \\
\text { olduğunu biliyorum }\end{array}$ & 47,5 & 52,5 \\
\hline $\begin{array}{l}\text { TÖMER marka adının Türkçe Öğrenim Merkezinden geldiğini } \\
\text { biliyorum }\end{array}$ & 44,1 & 55,9 \\
\hline TÖMER'in belirli kriterlere göre dil bursu verdiğini biliyorum & 30,5 & 69,5 \\
\hline TÖMER marka adını kullanan başka kurumlar olduğunu biliyorum & 20,8 & 79,2 \\
\hline TÖMER logosunu tam olarak hatırlayabiliyorum. & 46,5 & 34,4 \\
\hline
\end{tabular}

Anket kapsamında katılımcılara yöneltilen yukarıdaki ifadelerden, ilk üçü dışında farkındalığın az olduğu söylenebilir. Özellikle, TÖMER marka adını kullanan başka 
kurumlar olduğunu ve TÖMER'in dil bursu verdiğini bilen öğrenci oranı oldukça azdır. "Farkındalık (bilinirlik)" incelemesinde öğrencilere aynı zamanda TÖMER logosunu tam olarak hatırlayıp hatırlamadıkları sorulmuş ve öğrencilerin \% 46,5'inin hatırladığı, \% 34,4'ünün hatırlamadığı ve \% 19,1'inin ise tam olarak hatırlayamadığı gözlenmiştir.

Yukarıda belirtilen on ifade birlikte değerlendirilerek, her katılımcı için 100 üzerinden farkındalık puanlaması yapılmıştır. İzleyen bölümlerde 5'li Likert Ölçeği kullanılmıştır. Burada farklı bir puanlama yapıldığ içinde değerlendirilmesi doğru olacaktır. Buna göre katılımcıların genel farkındalık ortalaması 56,7 ile orta düzeyde bulunmuştur.

Yapılan istatistiksel analizlerde, öğrencilerin TÖMER hakkında hangi düzeyde bilgi sahibi oldukları ile farkındalık puanları arasında istatistiksel olarak fark olduğu $\left(\mathrm{KW}-\chi_{2}=74.834 ; \mathrm{p}=0,000\right)$ görülmüştür. Herhangi bir bilgi sahibi olmayan ve az düzeyde bilgi sahibi olanların puanları, istatistiksel olarak birbirinden farklı değilken $(\mathrm{U}=89.670,5, \mathrm{p}=0,833)$; üst düzeyde bilgi sahibi olduklarını belirten öğrencilerin farkındalığı diğer gruplara göre anlamlı olarak en yüksek düzeyde bulunmuştur (Tablo 2).

Tablo 2: Bilgi Düzeylerine Göre Öğrencilerin Marka Farkındalığı Puanları

\begin{tabular}{|l|c|c|}
\hline \multicolumn{1}{|c|}{ Bilgi Düzeyi } & Cevaplayan Öğrenci & Farkındalık Puanı \\
\hline Herhangi bir bilgi sahibi değilim & 284 & 53,3 \\
\hline Az düzeyde bilgi sahibiyim & 637 & 53,3 \\
\hline Orta düzeyde bilgi sahibiyim & 704 & 58,5 \\
\hline Üst düzeyde bilgi sahibiyim & 153 & 67,7 \\
\hline Toplam & 1778 & 56,7 \\
\hline
\end{tabular}

\subsection{Marka Çağrışımının Ölçülmesi}

Kursiyerlerin marka çağrışımını değerlendirmek için aşağıdaki üç soru sorulmuştur.

TÖMER yeniliklere ve gelişime açıktır.

TÖMER markası itibar sahibidir.

TÖMER markası güvenilirdir.

Öğrencilerin marka çağrışımı ile ilgili yukarıdaki ifadeler için 5'li Likert ölçeğinde (1-kesinlikle katılmıyorum, 5-kesinlikle katılıyorum) verdiği cevaplar 100 üzerinden hesaplandığında marka çağrışımı ortalaması 76,9 ile yüksek düzeyde bulunmuştur.

Yapılan istatistiksel analizlerde, öğrencilerin TÖMER hakkında hangi düzeyde bilgi sahibi oldukları ile marka çağrışım puanları arasında istatistiksel olarak fark olduğu (KW- $\chi 2=17.730 ; p=0,002)$ görülmüştür. TÖMER hakkında orta ve üst düzeyde bilgi sahibi olanların marka çağrışımı, az veya hiç bilgi sahibi olmayan öğrencilerden daha fazladir (Tablo 3). 
D. Ulaş - A. Tuzcu - E. Satıcı 10/4 (2018) 358-383

Tablo 3: Bilgi Düzeyine Göre Marka Çağrıșım Puanları

\begin{tabular}{|l|c|c|}
\hline \multicolumn{1}{|c|}{ Bilgi Düzeyi } & Öğrenci Sayısı & Çağrıșım Puanları \\
\hline Herhangi bir bilgi sahibi değilim & 251 & 76,8 \\
\hline Az düzeyde bilgi sahibiyim & 586 & 75,9 \\
\hline Orta düzeyde bilgi sahibiyim & 672 & 76,9 \\
\hline Üst düzeyde bilgi sahibiyim & 149 & 80,5 \\
\hline Toplam & 1658 & 76,9 \\
\hline
\end{tabular}

\subsection{Algılanan Kalitenin Ölçülmesi}

Algılanan kalite, tüketicilerin beklentilerinin tüketiciler açısından karşılanma düzeyidir. Tüketicilerin “TÖMER'den aldıkları dil eğitimi hizmeti hakkında algıladıkları kaliteye ilişkin olarak sorgulanan ifadeler aşağıda verilmiştir. $\mathrm{Bu}$ ifadeler için 5'li Likert ölçeğinde (1-kesinlikle katılmıyorum, 5-kesinlikle katılıyorum) verilen cevaplar 100 üzerinden değerlendirilerek algılanan kalite puanı hesaplanmıştır.

TÖMER'in geçtiğimiz y1llara göre daha iyiye gittiğini düşünüyorum.

TÖMER'i diğer dil kurslarıyla karşılaştırdığımda daha başarılı buluyorum.

TÖMER'i diğer dil kursları ile karşılaştırdığımda daha kaliteli buluyorum.

TÖMER'de sosyal etkinlikler yeterlidir.

Genel olarak TÖMER'de öğrenci olmaktan memnunum.

Öğretmenler güler yüzlüdür.

İdari personel güler yüzlüdür.

Öğretmenler öğrenciler ile ilgilidir.

İdari personel öğrenciler ile ilgilidir.

TÖMER çalışanları görüş ve önerilerimi dikkate alır.

TÖMER çalışanları şikâyetim olduğunda yardımcı olur.

Öğretmenler mesleki olarak yeterlidir.

Ders içerikleri yeterlidir.

Sınıfımın fiziksel koşulları yeterlidir.

Bulunduğum şubede sınıf ve tuvaletler temizdir.

Sınıfımın eğitim araçları (yansıtım, tv, dvd vb.) yeterlidir.

Eğitim araçlarının öğretmen tarafından etkin bir biçimde kullanıldığını düşünüyorum.

TÖMER web sayfası beklentilerimi karşılamaktadır.

TÖMER'i telefonla aradığımda cevap alabiliyorum.

TÖMER sayesinde, hedeflediğim başarı düzeyine ulaşacağımı düşünüyorum.

TÖMER genel olarak beklentilerimi karşılamaktadır.

Yukarıdaki ifadelere verilen cevaplar değerlendirildiğinde, öğrenciler tarafindan algılanan kaliteye ilişkin puan 67,5 olarak hesaplanmıştır. İfade bazlı inceleme yapıldığında ise, en yüksek puanlama "öğretmenler güler yüzlüdür" $(85,3)$ ve "öğretmenler öğrenciler ile ilgilidir" $(82,9)$ ifadeleri için yapılırken en düşük puanlamaya sahip ifadeler "TÖMER'de sosyal etkinlikler yeterlidir" (41,8) ve "TÖMER web sayfası beklentilerimi karşılamaktadır" (44,5) şeklindedir.

Ayrıca, öğrencilerin TÖMER hakkında hangi düzeyde bilgi sahibi oldukları ile algılanan kalite puanları arasında istatistiksel olarak fark olmadığı (KW- $\chi 2=1.660$; $\mathrm{p}=0,646$ ) görülmüştür (Tablo 4). 
Tablo 4: Bilgi Düzeyine Göre Algılanan Kalite Puanları

\begin{tabular}{|l|c|c|}
\hline \multicolumn{1}{|c|}{ Bilgi Düzeyi } & Öğrenci Sayısı & Algılanan Kalite Puanları \\
\hline Herhangi bir bilgi sahibi değilim & 284 & 67,2 \\
\hline Az düzeyde bilgi sahibiyim & 640 & 67,1 \\
\hline Orta düzeyde bilgi sahibiyim & 705 & 67,7 \\
\hline Üst düzeyde bilgi sahibiyim & 153 & 68,3 \\
\hline Toplam & 1782 & 67,5 \\
\hline
\end{tabular}

\subsection{Marka Sadakatinin (Bağlılığının) Ölçülmesi}

Marka sadakatini ölçmek için katılımcılara; tekrar satın alma, farklı dil eğitiminde de aynı markayı tercih etme, markanın ilk tercih olması, marka hakkında olumlu görüşe sahip olma, diğer markalar fiyat indirimi ve tanıtım yapsalar bile markayı değiştirmeme ve markayı diğerlerine tavsiyelerde bulunma vb. şeklinde sorular yöneltilmiştir. Aşağıdaki ifadeler için 5'li Likert ölçeğinde (1-kesinlikle katılmıyorum, 5-kesinlikle katılıyorum) verilen cevaplar 100 üzerinden değerlendirilerek öğrencilerin marka sadakati ölçülmüştür. Buna göre TÖMER öğrencilerinin ortalama sadakat puanı 68,1 olarak orta düzeyde bulunmuştur. Sadakat bileşenleri aşağıda listelenmektedir.

Şu an aldığım dil eğitimini TÖMER'de ilerletmeyi düşünürüm.

Şu an öğrendiğim dil dışında farklı bir dil öğrenmek için TÖMER'e devam etmeyi düşünürüm

TÖMER, yabancı dil öğrenimimde her zaman ilk tercihim olacaktır.

TÖMER'i bir aile, kendimi de onun bir ferdi olarak görüyorum.

Diğer dil kurslarının yapmış olduğu reklamlar TÖMER'e olan ilgimi azaltmaz.

Diğer kurslarda fiyat indirimi olsa da yine TÖMER'i tercih ederim.

TÖMER'de öğrenci olmayı başkalarına da tavsiye ederim.

Öğrencilerin TÖMER hakkındaki bilgi düzeyleri bakımından sadakat puanları arasında istatistiksel olarak anlamlı bir fark olduğu gözlenmiştir $\left(\mathrm{KW}-\chi^{2}=30.451\right.$; $\mathrm{p}=0,000)$. Farklılığı yaratan grupları belirlemek amacıyla yapılan ikili analizler sonucunda ise, herhangi bir bilgisi olmayan ya da az düzeyde bilgisi olduğunu ifade eden öğrencilerin sadakatlerinin, orta ve üst düzeyde bilgisi olduğunu düşünen öğrencilerin sadakatlerine göre daha düşük olduğu görülmüsştür (Tablo 5).

Tablo 5: Bilgi Düzeyine Göre Marka Sadakati Puanları

\begin{tabular}{|l|c|c|}
\hline \multicolumn{1}{|c|}{ Bilgi Düzeyi } & Öğrenci Sayısı & Sadakat Puanı \\
\hline Herhangi bir bilgi sahibi değilim & 282 & 66,3 \\
\hline Az düzeyde bilgi sahibiyim & 637 & 65,8 \\
\hline Orta düzeyde bilgi sahibiyim & 706 & 70,0 \\
\hline Üst düzeyde bilgi sahibiyim & 154 & 71,7 \\
\hline Toplam & 1779 & 68,1 \\
\hline
\end{tabular}

\section{Hipotez Testlerinin Sonuçları}

Test edilen model ile ilgili olarak yapılan korelasyon analizi sonucunda yokluk hipotezinin reddedildiği ve araştırılan ilişkilerin istatistiksel olarak anlamlı olduğu görülmüştür. Başka bir ifadeyle, marka denkliği bileşenleri arasında etkileşimli bir ilişkiler ağı mevcuttur. Bu bulgular, marka denkliği yapısının dört boyuttan (marka 
farkındalığı, algılanan kalite, marka çağrışımı ve marka sadakati) etkilenen bir süreç olduğunu düşünmemize neden olmaktadır.

$\mathbf{H}_{1}$ : Marka farkındalığı ve algılanan kalite arasında istatistiksel olarak anlamlı zayıf bir ilişki vardır (Spearman rho=0,223, $\mathrm{p}=0,000$ ).

$\mathbf{H}_{2}$ : Marka farkındalığı ve marka çağrışımı arasında istatistiksel olarak anlamlı zayıf bir ilişki vardır (Spearman rho=0,234, p=0,000).

$\mathrm{Bu}$ sonuçlar markadan farkında/haberdar olmanın marka denkliğinin oluşumu için yeterli olmadığını ima etmektedir. Farkındalık arttırdıkça, algılanan kalitenin artacağını ve markanın güvenilir, itibar sahibi, yeniliklere açık vb. çağnışımlara neden olacağını söylemek her şekilde mümkün görünmemektedir.

H3: Algılanan kalite ve marka çağrışımı arasında istatistiksel olarak anlamlı orta düzeyde bir ilişki vardır (Spearman rho=0,549, $\mathrm{p}=0,000$ ).

$\mathbf{H}_{4}$ : Algılanan kalite ve marka bağlılığı arasında istatistiksel olarak anlamlı orta düzeyde bir ilişki vardır (Spearman rho=0,640, $\mathrm{p}=0,000$ ).

Müşteriler bir markanın yüksek kaliteye sahip olduğunu algılarsa, bu markayı sürekli olarak almayı ve başkalarına tavsiye etmeyi tercih ederler (Jones, Mothersbaugh ve Beatty, 2002; de Ruyter, Wetzelz ve Bloemer, 1998). Bu durum, bir markanın iyi kaliteye sahip olduğunu algılamanın, markaya yönelik marka sadakatini artırmaya yardımcı olacağı anlamına gelir. Bu nedenle algılanan kalitenin marka çağrışımı ve marka sadakati üzerindeki etkisini görmek şaşırtıcı değildir.

H5: Marka çağrışımı ve marka bağ $\operatorname{ll}_{1} \breve{g ̆}_{1}$ arasında istatistiksel olarak anlamlı orta düzeyde bir ilişki vardır (Spearman $r h o=0,492, p=0,000$ ).

Bir markanın potansiyel değeri, özellikli çağrışımlara dayanmaktadır (Keller, 1993, Kim, Kim ve An, 2003; Low ve Lamb, 2000; Yoo, Donthu ve Lee, 2000). Marka sadakati, marka denkliğinin en önemli boyutudur. Chow ve Diğ.'nin (2017) çalışmasında marka çağrışımı, marka sadakati üzerinde en yüksek toplam etkiye sahiptir, daha sonra ise markanın algılanan kalitesi ve marka farkındalığ 1 gelmektedir. Çalışma, algılanan marka kalitesi ve marka çağrışımlarının marka sadakati açısından tahmin gücüne sahip olduğunu ortaya koymuştur.

$\mathrm{Bu}$ çalışmada ayrıca, marka sadakatinin marka denkliğinin diğer bileşenleri ile arasındaki sebep-sonuç ilişkisi çoklu regresyon analizi ile araştırılmıştır. Tam sayım ile anket çalışmasının yapılmış olması ve büyük veri seti ile çalışılıyor olmasından hareketle, merkezi limit teoremine göre normallik varsayımının sağlandığı kabul edilmiştir. Çoklu regresyon analizi ile elde edilen istatistiksel olarak anlamlı $(\mathrm{F}=532,678, \mathrm{p}=0,000)$ regresyon modeline göre marka farkındalığ algılanan kalitenin, marka sadakatini açıklamada anlamlı bileşenler olduğu görülmüştür. Bağımsız değişken olarak alınan algılanan kalite, marka çağrışımı ve farkındalığı, marka sadakatindeki değişimin \% 49'unu açıklamaktadır (Düzeltilmiş $\mathrm{R}^{2}=0,49$ ). 
Tablo 6: Regresyon Analizi Katsayılar Tablosu

\begin{tabular}{|c|c|c|c|c|c|c|c|c|}
\hline \multirow{6}{*}{1} & \multirow{2}{*}{ Model } & \multicolumn{2}{|c|}{ Katsay 1} & \multirow{2}{*}{$\begin{array}{c}\text { Standart } \\
\beta\end{array}$} & \multirow{2}{*}{$\mathrm{t}$} & \multirow{2}{*}{$\mathrm{p}$} & \multicolumn{2}{|c|}{$\begin{array}{l}\text { Çoklu Bağlantı } \\
\text { İstatistikleri }\end{array}$} \\
\hline & & $\begin{array}{c}\text { Standart } \\
\beta\end{array}$ & $\begin{array}{l}\text { Standart } \\
\text { Hata }\end{array}$ & & & & Tolerans & VIF \\
\hline & Sabit & 7,238 & 1,630 & & 4,440 & 0,000 & & \\
\hline & Algilanan Kalite & 0,643 & 0,026 & 0,555 & 25,165 & 0,000 & 0,631 & 1,584 \\
\hline & Marka Çağrışımı & 0,157 & 0,021 & 0,164 & 7,447 & 0,000 & 0,632 & 1,582 \\
\hline & Marka Farkındalığı & 0,101 & 0,016 & 0,112 & 6,211 & 0,000 & 0,946 & 1,057 \\
\hline
\end{tabular}

Tablo 6'da verilen standart katsayı değerlerinden, marka bağlılı̆̆ yaratma konusunda en önemli değişkenin algılanan kalite olduğu sonucuna ulaşılmaktadır. Bununla birlikte tabloda verilen istatistiksel olarak anlamlı $(p<0,05)$ katsayı değerleri kullanılarak aşağıdaki eşitlik elde edilmiştir.

Marka Sadakati $=7,238+0,643$ Kalite $+0,157$ Çağrışım $+0,101$ Farkındalık

Buna göre; algılanan kalitedeki 10 puanlık artışın, marka sadakatinde 6,43 puanlık bir artışa sebep olduğu söylenebilir. Ayrıca marka çağrışımı ve marka farkındalığının marka sadakati üzerinde pozitif etkisi olduğu görülmektedir.

Son olarak marka denkliğinin bileşenleri olan dört boyut, faktör analizi yoluyla iki faktöre indirgenmiştir. Marka denkliğindeki toplam değişimin \% 80'inin bu iki faktör vasıtasıyla açıklanabildiği görülmektedir. Faktör analizine ilişkin ayrıntılı sonuç tabloları Ek-1'de verilmiştir. İlk faktörde algılanan kalitenin, ikinci faktörde marka farkındalığının daha etkili olduğu (temel yüklere göre) görülmektedir. Analiz sonucunda elde edilen ve özdeğerleri birden büyük iki temel bileşen, varyans açıklama oranlarına göre ağırlık toplamı bir olacak şekilde ağırlıklandırılmış ve böylelikle araştırmaya katılan öğrenciler açısından marka denkliği endeks değerleri elde edilmiştir. $\mathrm{Bu}$ değerler, yorumlamaya imkan verebilmek için 0-100 aralığına getirilmiştir. Sonuç olarak, TÖMER öğrencilerinin faktör analizi sonucu elde edilen marka denkliği değerlendirmesi 100 üzerinden 65,4 olarak hesaplanmıştır. Bu sonuç öğrencilerin marka boyutlarına ilişkin olarak yapmış oldukları değerlendirmelerin ne çok iyi ne de çok kötü olduğuna işaret etmektedir. TÖMER'in belli bir marka değeri olduğu anlaşılmakla birlikte bu markanın daha da değer kazanmasını sağlamak için yönetim tarafından aşağıda vurgulanan bir takım adımların atılmasının markanın daha da değerlenmesi için gerekli ve önemli olduğu düşünülmektedir.

\section{Sonuç ve Tartışma}

Marka denkliği yüksek olan markaların; farkındalığı, çağrışımı, algılanan kalitesi ve sadık tüketicileri de fazla olmaktadır. Tüketiciler farkında oldukları ürünü ve hizmeti tercih etmektedir. Piyasada güçlü marka denkliği oluşturmak, ürünü/hizmeti rakiplerinden ayırt etmek önemli bir stratejidir. Bu çalışmada da, TÖMER hakkında orta ve yüksek düzeyde bilgi sahibi olduğunu belirten öğrencilerin, marka farkındalı̆̆g, algılanan kalite ve marka sadakatinin TÖMER hakkında hiç bilgi sahibi olmadığını veya az düzeyde bilgi sahibi olduğunu belirten öğrencilerden anlamlı düzeyde yüksek olduğu görülmüştür. Bu sonuç, mevcut ve potansiyel kursiyerlerin TÖMER hakkındaki bilgilerinin arttırılmasının TÖMER'in marka denkliğine yapacağı katkıyı ortaya koymaktadır. 
Marka denkliği, iyi bir pazarlama stratejisi ile uzun vadede inşa edilebilir. Bu çalışmada TÖMER için Aaker $(1991,1996)$ tarafından geliştirilen marka denkliği bileşenleri incelenmiştir. TÖMER'in, marka denkliği bileşenleri bağlamında öğrencileri tarafından nasıl algılandığı, TÖMER'e yönelik bir marka sadakatinin olup olmadığı belirlenmeye çalışılmıştır. Ayrıca, bu bileşenler kullanılarak istatistiksel olarak TÖMER için marka denkliği hesaplanmıştır. Çalışmanın sonuçları kurumların yöneticileri tarafından markalarını geliştirmek ve daha etkili stratejiler uygulamak için kullanabilir. Marka denkliğini yükseltmeyi amaçlayan bir markanın yöneticileri, marka sadakatini teşvik için öncelikli olarak marka çağrışımlarını güçlendirmeli, ardından da markanın algılanan kalitesini arttırmaya yönelmelidir. Marka denkliğinin bileşenlerini güçlendirmek için TÖMER'e yönelik şu öneriler yapılabilir.

Marka Farkındalığı: Ankara Üniversitesi bünyesinde yürütülen TÖMER faaliyetlerinin özellikle Ankara'da bir farkındalığı olmakla birlikte hali hazırda ülke çapında yürütülen tanıtım ve reklam faaliyetleri yeterli düzeyde değildir. Ayrıca, özel sektör tarafından yürütülen her tür reklam ve özendirme faaliyetlerine karşı merkez ve şubelerce alternatif stratejiler geliştirmekte güçlükle karşılaşılmaktadır. Bir kurumun sahip olduğu markanın gelişmesi için en önemli unsurlarından bir tanesi markanın yeterli düzeyde tanıtımının yapılması ve marka adının duyurulmasıdır. TÖMER için reklam ve tanıtımın yeterli düzeyde yapılması büyük önem taşımaktadır. TÖMER'de, reklam için herhangi bir bütçe ayrıl(a)mamakta ve bu nedenle kurumun tanıtımı yeterince yapılamamaktadır. Ankara Üniversitesi ve TÖMER' in uluslararası bağlantılar kurulabilme imkânının bulunması sayesinde yapılacak protokoller yoluyla TÖMER'in tanıtımının güçlendirilmesi sağlanabilir. Marka yaratmada sadece reklam yapılması yeterli olmamaktadır. Müşteriler, markayı kişisel gözlem ve kullanım, ağızdan ağza iletişim, işletme çalışanı ile etkileşim, online ya da telefonda iletişim deneyimleri ve ödeme işlemleri kolaylıkları gibi bir dizi etkileşim aracılığıyla tanımaktadır. Marka iletişimi müşterinin markayla, ürünle, pazarla ilgili sağladığı her türlü deneyimdir. Kurumun göstereceği çaba markaya karşı tüketicilerin duyguları, düşüncelerini ve eylemlerini etkileyebilir. Marka iletişimi sağlamak için günümüzde online topluluklar, sponsorluklar, fuarlar, etkinlik pazarlaması, halkla ilişkiler, basın bültenleri kullanılabilir. İlan panolarında reklam, üniversitelerde duyuru ve ilanlar verilebilir, kariyer günlerinde tanıtım yapılabilir. Diğer taraftan markayı oluşturan marka öğeleri ya da kimlikleriyle ilgili (marka isimleri, logolar, semboller, karakterler, sözcü/temsilciler, sloganlar, tanıtım müzikleri, ambalajlama, işaretler vb.) unsurlar farkındalık sağlanması açısından etkilidir.

Marka Çağrışımı: Çeşitli sunumlarla marka (Ankara Üniversitesi, TÖMER) tarihi ve kültürü vurgulanabilir. Marka denkliği yaratılırken kurumda çalışan bireyler de bu değerin oluşmasında aktif rol oynamaktadır. Çalışanlar işletmenin yüzü ve temsilcisi olarak görülmektedirler, bu yüzden de çalışanların markayı benimsemeleri ve ona sadakat duygusu beslemeleri sağlanmalıdır. Çağrışımlar çalışanların hizmet sunum kalitesine, rakiplerden farklılığına, inovasyon, prestij veya fiziksel koşullar ile ilgili olabilir. Avrupa Dil Portfolyosuna denk bir dil belgesi verdiği, yabancı uyruklu öğrencilere verilen Türkçe yeterlilik diplomasının Türkiye'deki tüm üniversitelerde geçerli olduğu daha fazla vurgulanabilir. Markaya karşı olumlu tutumlar ve hisler oluşturulurken TÖMER'de eğitim almanın sağlayacağı faydalar daha fazla vurgulanabilir ve tüketicilerin zihinlerinde marka anlamı yerleştirilebilir.

Algılanan Kalite: Algılanan kalite marka hakkında hissedilen algılar, yargılar, düşünceler ve inançlardır. Güvenilirlik ve performansa, hizmetin güvenilirliğine, 
garantilere, fiziksel koşullara ilişkin olabilir. TÖMER tarafından verilen diplomaların ulusal ve uluslararası geçerliliği, kurumun itibarını ve kalitesini artırmaktadır. Bu itibar ve güçle ulusal ve uluslararası platformlarda akademik işbirlikleri ve anlaşmalar yapılabilir. Yurt içinde ve dışında, Türkçe ve yabancı dil eğitimi konusunda lider bir kurum konumuna gelinebilir. Ülke dışında dil okullarıyla işbirliği yapılması yoluyla başta Ankara Üniversitesi ve TÖMER'e kaynak sağlanabilir. Gönüllü kültür elçileri yaratılarak Ankara Üniversitesi, TÖMER ve ülkemizin tanıtımı sağlanabilir. Teknolojideki gelişmeler takip edilerek mekânsal sınırlara bağlı kalmadan, uzaktan eğitim yoluyla dil eğitimi dünya çapında verilir hale getirilebilir. Örnek derslere, kursa kayıt yaptırmayı düşünen kişiler davet edilebilir. Yabancı öğrencilerle, Türk öğrenciler arasında dil ortaklığı oluşturulabilir. Ülke dışında dil araştırma kurumlarıyla işbirliği yapılarak dönem dönem ülke dışına öğrenci gönderilebilir ya da ülke dışından ögrenciler misafir edilebilir.

Marka Sadakati: Marka sadakati yaratmak için sadık tüketicilerin memnuniyetlerinin ve devamlılığının sağlanması önerilmektedir. Öğrencilerin aldıkları hizmetin tatmin düzeyi ölçülerek, öğrencilerin beklentilerine, isteklerine, şikâyetlerine ve algılanan kaliteye önem verilerek öğrenci merkezli hizmet üretim süreci oluşturulabilir. Kampanyalar ve sosyal medya daha etkin kullanılabilir. Teknolojinin hızla gelişmesiyle iletişim ve ulaşım imkânlarının artmasıyla öğrencilerin de ihtiyaçları, tutumları, öğrenme stilleri ve algıları zaman içinde değişmektedir. Müşterilerle duygusal bağ oluşturmanın en temel faktörü sağlıklı iletişim kurmak, çözüm odaklı ve ulaşılabilir olmak, kaliteli hizmet sunmaktır. Yönetimin kendini yeni trendlere uyarlaması, okutmanlarla ve öğrencilerle iyi bir iletişim ve işbirliği kurması önemlidir. Müşteri ilişkileri inşa edilebilir; üyelik, dil partneri (Türk-Alman gibi) uygulamaları geliştirilebilir. Erasmus programlarında olduğu gibi üniversitelerle protokol yapılarak TÖMER öğrencilerine, misafir öğrenci olarak belirli bir süre için ülke dişında dil pratiği yapma imkânları sağlanabilir. Çalışma sonucunda marka bağlılığını artırmak için sunulan hizmet kalitesini artırmanın diğer bileşenlerden daha etkili olduğu görülmüştür.

Marka tescilinin yaptırılması markanın aynı veya benzer mal ve hizmetler için izinsiz kullanımını engeller. Ankara Üniversitesi "TÖMER" markası 13.08.2013 tarihinde tescil edilmiştir. Bu sayede TÖMER markasının kullanımı ve ticarileştirilmesi yalnızca Ankara Üniversitesi tarafından yapılabilir hale gelmiştir. Dil eğitimi sektörüne girmeyi düşünen girişimcilerin veya hali hazırda farklı isimler altında faaliyet gösteren dil merkezlerinin TÖMER adını kullanmayı istemeleri sağlanabilir. TÖMER'in sahip olduğu tanınırlık, imaj ve marka denkliği, ticari açıdan orta ve uzun vadede gelir yaratma potansiyeli taşımaktadır. Ankara Üniversitesi'nin tescilli TÖMER marka adının kullandırılmasıyla, Ankara Üniversitesi'ne gelir yaratılabilir.

Çalışmada tüketici bakış açısıyla tek markanın (TÖMER'in) marka denkliği bileşenleri araştırılmıştır. Öğrencilerin TÖMER'in marka denkliği bileşenleri ölçülmeye çalışılmıştır. İlerideki çalışmalarda diğer dil eğitimi veren birden fazla markanın denkliği karşılaştırmalı olarak araştırılabilir. Başarılı ve başarısız uygulamaların sonucunda ortaya çıkan marka denkliği bileşenleri arasındaki farklar karşılaştırılıp, kıyaslama yapılabilir. Çalışanların TÖMER markası algıları dikkate alınarak, çalışan bakış açısıyla marka denkliği analizi de yapılabilir. Yapılan araştırmalar çoğunlukla tüketicinin marka sadakati üzerinde yoğunlaşmaktadır. İleride marka denkliği oluşturma sürecine dahil olma ve tüketici katılımını etkileyen faktörler üzerinde de çalışmalar yapılabilir. 


\section{KAYNAKÇA}

Aaker, D. A., (1991). Managing Brand Equity, Capitalizing on the Value of a Brand, The Free Press.

Aaker, D. A., (1996). "Measuring brand equity across products and markets", California Management Review, Vol. 38, No. 3, 102-120.

Alexandris, K., Douka, S., Papadopoulos, P., Kaltsatou, A. (2008).”Testing the role of service quality on the development of brand associations and brand loyalty", Managing Service Quality, 18, 239-254.

Ar, A. A., (2004). Marka ve Marka Stratejileri, Detay Yayıncılık, 3. Baskı, Ankara.

Aydın, S., Özer, G., (2005). "The analysis of antecedents of customer loyalty in the Turkish mobile telecommunication market", European Journal of Marketing, 39(7/8), 910-925.

Baalbaki S., Guzman F., (2016). "Consumer-based brand equity”, The Routledge Companion to Contemporary Brand Management, Chapter: 3, Publisher: Routledge, Editors: Francesca Dall'Olmo Riley, Jaywant Singh, Charles Blankson, https://www.researchgate.net/publication/309478932 Consumerbased brand equity, Erişim Tarihi: 8.8.2018

Budac, C., Baltador, L., (2013). "The value of brand equity", Procedia Economics and Finance 6, 444-448.

Boyle, E. (2007). “A Process Model of Brand Cocreation: Brand Management and Research Implications”, Journal of Product \& Brand Management, 16, 122 - 131.

Chieng, F., Lee, C. G., (2011). "Customer-based brand equity: a literature review", Journal of Arts Science \& Commerce, International Refereed Research Journal, Vol. 2, Issue 1, 33-42.

Chow, H., Ling G., Yen I., Hwang, K., (2017). "Building brand equity through industrial tourism", Asia Pasific Management Review, 22, 70-79.

Farjam, S., Hongyi, X., (2015). "Reviewing the concept of brand equity and evaluating consumer based brand equity (CBBE) Models", International Journal of Management Science and Business Administration, Vol. 1, Issue 8, 14-29.

Fayrene Chieng Y. L., Lee G, C., (2011). "Customer based brand equity: A literature review", Journal of Arts Science \& Commerce, Vol. 2, Issue 1, 33-42.

Foroudi, P., Jin Z., Gupta S., Foroudi M. M., Kitchen, P. J., (2018). "Perceptional components of brand equity: Configuring the symmetrical and asymmetrical paths to brand loyalty and brand purchase intention”, Journal of Business Research, 89, $462-474$.

Gartner, W. C., Konecnik Ruitner, M. (2011). "Tourism destination brand equity dimensions: Renewal versus repeat market", Journal of Travel Research, 50(5), 471-481.

Hoeffler, S., Keller, K. L., (2003). "The marketing advantages of strong brands", Brand Management, Vol 10, Issue 6, 421-445. 
https://www.ama.org/resources/Pages/Dictionary.aspx?dLetter=B\&dLetter=B $\quad$ Erişim Tarihi: 15.8.2018

Jones, M. A., Mothersbaugh, D. L., Beatty, S. E., (2002). "Why customers stay: Measuring the underlying dimensions of services switching costs and managing their differential strategic outcomes", Journal of Business Research, 55(6), 441450 .

Keller, K. L., (1993). "Conceptualizing, measuring and managing customer based brand equity", Journal of Marketing, 57(1), January, 1-22.

Keller, K. L., (2002). "Branding and brand equity", http://bear.warrington.ufl.edu/weitz/mar7786/Articles/Keller\%202002.pdf, Erişim Tarihi: 8.8.2018.

Keller, K. L., (2010). "Brand Equity Management in a multichannel, multimedia retail environment", Journal of Interactive Marketing 24, 58-70.

Kim, H. B., Kim, W. G., An, J. A., (2003). "The effect of consumer-based brand equity on firms' financial performance", Journal of Consumer Marketing, 20(4), 335351.

Kircova, İ., (2018). Kotler P., Keller K. L.'dan, çev., Pazarlama Yönetimi, Birinci bask1, Beta Basım Yayım.

Krystallis, A., Chrysochou, P., (2014). "The effects of service brand dimensions on brand loyalty", Journal of Retailing and Consumer Services, 21, 139-147.

Kuhn, K. L., Alpert, F., Pope, N. K., (2008). ”An application of Keller's brand equity model in aB2B context", Qualitative Market Research: An International Journal, Vol. 11, Issue 1, $40-58$.

Kuvykaite, R., Piligrimiene, Z., (2014). "Consumer engagement into brand equity creation", Procedia - Social and Behavioral Sciences, 156, 479 - 483.

Lin, C., Wu, W., Wang, Z., (2000). "A study of market structure: Brand loyalty and brand switching behaviors for durable household appliances", International Journal of Market Research, Vol. 42, Issue 3, 277-300.

Liu, M. T., Ipkin A. W., Ting-Hsiang, T., Wen-Yu Chang, A., Phaue, I., (2017). "Applying consumer-based brand equity in luxury hotel branding", Journal of Business Research 81, 192-202.

Low, G. S., Lamb, C. W., (2000). "The measurement and dimensionality of brand associations", Journal of Product \& Brand Management, 9 (6), 350-370.

McConnell, J. D., (1968). "The development of brand loyalty: An experimental study", Journal of Marketing Research, Vol. V, February, 13- 19.

Miller, A. R., Grazer, W. F., (2003). "Complaint behavior as a factor in Cruise line losses: An Analysis of Brand Loyalty", Journal of Travel\&Tourism Marketing, Vol. 15(1), 77-91.

Park, J. W., Robertson, R., Wu, C. L., (2004). "The effect of airline service quality on passengers' behavioural intentions: A Korean case study", Journal of Air Transport Management, 10(6), 435-439. 
Pitta, D. A., Katsanis, L. P., (1995). "Understanding brand equity for successful brand extension”, Journal of Consumer Marketing, Vol. 12, Issue:4, 51-64.

de Ruyter, K., Wetzels, M., Bloemer M., J., (1998). "On the relationship between perceived service quality, service loyalty and switching", International Journal of Service Industry Management, Vol. 9, No. 5, 436-453.

Seongseop, S. K., Choeb, J. Y. J., Petrickc, J. F., (2018). "The effect of celebrity on brand awareness, perceived quality, brand image, brand loyalty, and destination attachment to a literary festival", Journal of Destination Marketing \& Management, 9, 320-329.

Steenkamp, J. B., (1997). "Dynamics in consumer behaviour with respect to agricultural and food products in Agricultural", Marketing and Consumer Behaviour in a Changing World, Kluwer Academic Publishers.

Vazquez, R., Del Rio A. B., Iglesias, V., (2002), "Consumer based brand equity: development and validation of a measurement instrument", Journal of Marketing Management, Vol.18, No. 6, 27-48.

Villarejo-Ramos, A. F., Sanchez-Franco, M. J., (2005). "The impact of marketing communication and price promotion on brand equity", Journal of Brand Management, 12(6), 431-444.

Yoo, B., Donthu, N., Lee, S., (2000). "An examination of selected marketing mix elements and brand equity", Journal of the Academy of Marketing Science, 28(2), 195-211.

Zeithaml, V. A., (1988). "Consumer perceptions of price, quality, and value: a meansend model and synthesis of evidence", Journal of Marketing, 52(3): 2-22. 


\section{Ek-1: Marka Denkliği Faktör Analizi Çıktı Tabloları}

\section{KMO ve Bartlett Testi}

KMO and Bartlett's Test

\begin{tabular}{l|r|r}
\hline Kaiser-Meyer-Olkin Measure of Sampling Adequacy. &, 717 \\
\hline \begin{tabular}{l|r} 
Bartlett's Test of \\
Sphericity
\end{tabular} & Approx. Chi-Square & 1956,650 \\
\cline { 2 - 3 } & df & 6 \\
\hline Sig. &, 000 \\
\hline
\end{tabular}

\section{Temel Bileşenler Tablosu}

\begin{tabular}{|c|c|c|c|c|c|c|c|c|c|}
\hline \multicolumn{10}{|c|}{ Total Variance Explained } \\
\hline \multirow[b]{2}{*}{ Component } & \multirow[b]{2}{*}{ Total } & \multicolumn{2}{|c|}{ Initial Eigenvalues } & \multicolumn{3}{|c|}{ Extraction Sums of Squared Loadings } & \multicolumn{3}{|c|}{ Rotation Sums of Squared Loadings } \\
\hline & & $\%$ of Variance & Cumulative \% & Total & $\%$ of Variance & Cumulative $\%$ & Total & $\%$ of Variance & Cumulative $\%$ \\
\hline 1 & 2,318 & 57,950 & 57,950 & 2,318 & 57,950 & 57,950 & 2,178 & 54,455 & 54,455 \\
\hline 2 &, 887 & 22,177 & 80,127 &, 887 & 22,177 & 80,127 & 1,027 & 25,672 & 80,127 \\
\hline 3 & 488 & 12,208 & 92,335 & & & & & & \\
\hline 4 & , 307 & 7,665 & 100,000 & & & & & & \\
\hline
\end{tabular}

\section{Temel Bileşenler Yük Matrisi}

\section{Component Score Coefficient Matrix}

\begin{tabular}{lc|c} 
& \multicolumn{2}{c}{ Component } \\
& 1 & 2 \\
\hline baglilik_sadakat_yuzluk &, 381 &, 018 \\
\hline Ort_Kalite100 &, 427 &,- 095 \\
\hline cagrisim_yuzort_s42_s4 &, 391 &,- 080 \\
3_6sız & & \\
\hline Farkinda_Puan &,- 139 & 1,022 \\
\hline $\begin{array}{l}\text { Extraction Method: Principal Component Analysis. } \\
\text { Rotation Method: Varimax with Kaiser }\end{array}$ \\
$\begin{array}{l}\text { Normalization. } \\
\text { Component Scores. }\end{array}$
\end{tabular}




\title{
The Analysis of Customer Based Brand Equity Components of Ankara University TÖMER
}

\author{
Dilber ULAŞ \\ Ankara University \\ Faculty of Political Science \\ Ankara, Turkey \\ orcid.org/0000-0002-7892-2406 \\ ulas@politics.ankara.edu.tr
}

\author{
Arcan TUZCU \\ Ankara University \\ Faculty of Political Science \\ Ankara, Turkey \\ orcid.org/0000-0001-6342-735X \\ tuzcu@,politics.ankara.edu.tr
}

\author{
Esra SATICI \\ General Directorate of Highways \\ Ankara, Turkey \\ orcid.org/0000-0002-6784-182X \\ esra.satici@gmail.com
}

\section{Extensive Summary}

\section{Introduction}

According to Aaker (1991), brand equity is defined as "the elements which increase or decrease the value attributed to a firm by a product or a service." Briefly, it is identified with "the value consumers attribute to a brand" (Aaker, 1991). Within the framework of the existing literature, brand equity has been analyzed on financial, employee, and consumer bases. Consumer based brand equity is mainly interested in the decision-making process of the consumers from a marketing perspective and allows the researcher to reveal, in a more effective way, how the brand is evaluated by the consumer (Farjam and Hongyi, 2015, p. 15).

Aaker (1991) also notes that consumer based brand equity components include brand awareness, perceived quality, brand image, and brand loyalty. In other words, this type of brand equity reveals itself when consumers know the brand, when they are highly aware of the brand, and when the brand has powerful associations in their memory. While brand awareness influences the perceived quality and brand association, the perceived quality influences brand loyalty. When consumers associate the brand with high quality, their sympathy and addiction to the brand increases. As a result, brand loyalty increases and consumers tend to become constant users.

\section{Objective of the Study}

The purpose of the present study is to assess TÖMER's brand equity components and to determine the relationship between these components. Moreover, the relation brand loyalty has with brand association, brand awareness, and the perceived quality of the brand was investigated. Finally, TÖMER's brand equity was calculated by means of brand equity components. 


\section{Sample and Methodology}

The research population includes all the native and foreign students registered in all the branches of TÖMER. Before the selection of the sample, questionaires were submitted to all of the students and 1801 (60.6\%) students out of 2983 gave feedback.

In order to evaluate the dimensions that constitute the brand value of TÖMER, affirmations used in the multidimensional scale of consumer based brand equity, developed by Aaker (1991, 1996), Zeithaml (1988), Keller (1993), Pitta and Katsanis (1995), Miller and Grazer (2003), Krystallis and Chrysochou (2014), and Baalbaki and Guzmán (2016), has been used. By means of the five point likert scale, participants were asked to express to what extent they agree with the affirmations. Reliability analyses regarding the 39 questions of the survey proved that the scale was highly reliable since Cronbach's alpha value was calculated as 0.903 .

\section{Research Model}

In this study, the four components of brand equity were evaluated. The research model is represented in Figure 1. From this point of view, the hypotheses mentioned below were formed.

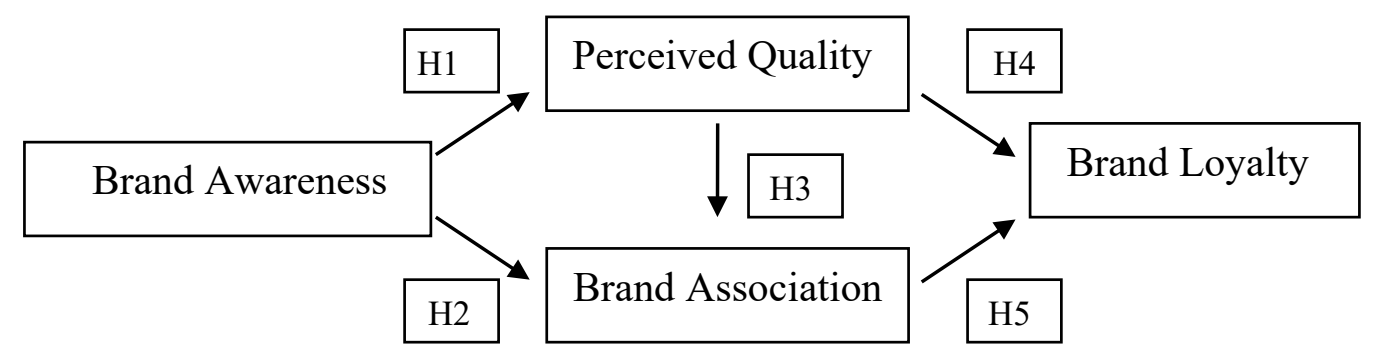

Figure 1: Brand Equity Components Model

Brand awareness is the basis of brand equity (Gartner and Konecnik Ruzzier, 2011). Accordingly, brand awareness leads to a better perceived quality (Yoo and Donthu, 2000), and a better brand association (Villarejo-Ramos and Sanchez-Franco, 2005). Therefore, the following hypotheses are constructed.

$\mathrm{H}_{1}$ : Brand awareness is related to perceived quality.

$\mathrm{H}_{2}$ : Brand awareness is related to brand association.

Park, Robertson and $\mathrm{Wu}$ (2004) argue that perceived quality affects brand awareness positively. Aydın and Özer (2005) emphasize that brand image in closely originates from consumers' cumulative experiences, and from the perceived quality of the service and the product. For this reason, it is possible to conclude that perceived quality will directly influence brand association. Furthermore, consumers tend to constantly buy a specific brand and to recommend it to others when they perceive it to be of high quality (Jones, Mothersbaugh and Beatty, 2002, de Ruyter, Wetzelz and Bloemer, 1998). This attitude signals that the perception that the brand is of high quality will help increasing brand loyalty. As a result, third and fourth hypotheses are formed. 
$\mathrm{H}_{3}$ : Perceived quality is related to brand association.

$\mathrm{H}_{4}$ : Perceived quality is related to brand loyalty.

Brand associations have a strong positive effect on brand loyalty (Park, Robertson and $\mathrm{Wu}, 2004)$. In other words, if a specific brand has a powerful brand association, people are more loyal to the brand. Hence, the fifth hypothesis is as follows:

$\mathrm{H}_{5}$ : Brand association is related to brand loyalty.

Lastly, it can be seen that the first three components of the model (brand awareness, brand association, and perceived quality) are the determinants of brand loyalty (Chow et al., 2017).

$\mathrm{H}_{6}$ : Brand loyalty is influenced by brand awareness, brand association, and perceived quality.

\section{Testing the Hypotheses}

Brand equity components were obtained by evaluating the answers on a scale of a hundred. Reliability tests were realized for brand equity components to evaluate whether they were internally consistent. As questions aimed at measuring brand awareness are not prepared according to the five point likert scale, the score regarding awareness was calculated by means of weighted average. In order to investigate the significant difference between components, which do not show a normal distribution, nonparametric statistical techniques were employed in independent sample tests (Kruskall Wallis and Mann-Whitney U test). The relation between the components of brand equity was examined through Spearman rank correlation analysis. In addition, multiple regression analysis was employed in order to test whether brand loyalty can be explained as a function of brand awareness, perceived quality, and brand association variables, to study the causality relationship, and to see their co-movements together.

Finally, brand equity index values were obtained through factor analysis, which was carried out by means of the four components. Index values obtained were brought to the interval of $0-100$ by interpolation to facilitate their interpretation.

\section{Findings and Discussion}

$60.8 \%$ of the students who participated to the survey filled in the questionnaire in Turkish, while $39.2 \%$ of them filled in the forms prepared in six different languages. $63.7 \%$ of the participants are women and $36.3 \%$ of them are man. $51 \%$ of the respondents hold an undergraduate or graduate degree. The average age is 25 .

Brand equity was assessed according to the recalling level of the TÖMER logo and brand information. From the nine affirmations addressed to participants - except three of them - it can be concluded that participants TÖMER's brand awareness is weak and that an average of $46.5 \%$ of participants remember the logo. These ten affirmations were evaluated together in order to score awareness out of 100 for each participant and it was found that the score is 56.7 out of 100 , which can be interpreted as average.

The calculation of students' answers for the affirmations regarding brand association, perceived quality and brand loyalty on the five point likert scale showed that while brand association is high with a 76.9 score out of 100 , perceived quality (67.5) and brand loyalty (68.1) are medium. 
The results for each hypothesis are given below:

$\mathbf{H}_{1}$ : From a statistical point of view, there is a significantly weak relation between brand awareness and perceived quality (Spearman rho $=0.223, \mathrm{p}=0.000$ ).

$\mathbf{H}_{2}$ : From a statistical point of view, there is a significantly weak relation between brand awareness and brand association (Spearman $\mathrm{rho}=0.234, \mathrm{p}=0.000$ ).

These results imply that to be aware/informed of a brand is not enough for the formation of brand equity. It is, by all means, not possible to state that the more awareness about a brand increases the more it will be perceived as reliable, highly regarded, and innovative.

$\mathbf{H}_{3}$ : From a statistical point of view, there is a significantly medium relation between perceived quality and brand association (Spearman rho $=0.549, \mathrm{p}=0.000$ ).

$\mathbf{H}_{4}$ : From a statistical point of view, there is a significantly medium relation between perceived quality and brand loyalty (Spearman rho=0.640, $\mathrm{p}=0.000$ ).

If consumers believe that a specific brand is of high quality, they tend to recommend it to others (Jones, Mothersbaughdand Beatty, 2002, de Ruyter, Wetzelz and Bloemer, 1998). This means that the perception that a brand is of high quality helps increasing brand loyalty. It is, thus, not surprising to observe the effect of perceived image on brand association and brand loyalty.

$\mathbf{H}_{5}$ : From a statistical point of view, there is a significantly medium relation between brand association and brand loyalty (Spearman rho $=0.492, \mathrm{p}=0.000$ ).

The potential value of a brand is based on specific associations (Keller, 1993, Kim et al., 2003, Low and Lamb, 2000, Yoo et al., 2000). Brand loyalty is the most crucial dimension of brand equity. The study of Chow et al. (2017) reveals that perceived brand quality and brand associations have a prediction power in terms of brand loyalty.

In our study, the causality relationship between brand loyalty and other components of brand equity was also examined by means of multiple regression analysis. According to the statistically significant $(\mathrm{F}=532.678, \mathrm{p}=0.000)$ regression model obtained from multiple regression analysis, it was observed that brand awareness, brand association, and perceived quality are statistically significant components to explain brand loyalty. Altogether perceived quality, brand association and awareness explain $49 \%$ of the changes in brand loyalty.

\section{Brand loyalty $=7.238+0.643$ Quality +0.157 Association +0.101 Awareness}

It was also observed that the most important variable in creating brand loyalty is perceived quality. Furthermore, brand association and awareness have a positive influence on brand loyalty.

Finally, the four components of brand equity were reduced to two factors by means of factor analysis. It can be seen that $80 \%$ of the total variation in brand equity can be explained by means of these two factors. 2 factors which obtained through the analysis and whose eigenvalues are greater than 1 are weighted according to their percentages of total variance explained where the total weights sum up to 1 . Thus, brand equity index values from the point of view of the students who attend to the study were obtained. 
These values were converted to a scale of $0-100$ in order to facilitate the interpretation. As a result, TÖMER's brand equity score, obtained from factor analysis, was calculated as 65.4 out of 100 . This finding indicates that evaluation made by students regarding brand equity dimensions is neither very good nor very bad.

Consumers choose products and services they are aware of. This study reveals that the number of students who stated that their knowledge about TÖMER is medium and high is superior to the number of students who affirmed that they are not aware of or have little information about TÖMER. This finding suggests that increasing the current and potential knowledge of the students registered to TÖMER would contribute to the brand's equity. 